\title{
Cultural Concept in Terms of Philosophy in Russian Linguistics
}

\author{
Paulina Loginova \\ International communication department, \\ Faculty of world politics \\ Moscow Lomonosov State University \\ Moscow, Russia \\ E-mail: polina-loginova@inbox.ru
}

\begin{abstract}
The paper goes on analysis of the cultural concept issue that is widely investigated in Russian cognitive linguistics. It is attempted to depict briefly the most outstanding research trends that envisage culture concept as a mental formation in terms of language units in Russian philological science in the light of philosophy. The survey of concepts of culture investigated in Russian linguistics illustrates that abovementioned cognitive units act as multidimensional mental complexes and reflect the perception of ethnocultural heritage as well as specifics of peoples' mentality. Examples of phraseological units that verbalize concepts of culture reviewed by the author prove that by the means of paroemias nominating various concepts of spiritual, material and social culture, there is a possibility to distinguish differences and similarities of the nations' mentalities.
\end{abstract}

Keywords-cultural concept; paroemia; Russian cognitive linguistics; outworld; linguoculturology; mentality; national character

\section{INTRODUCTION}

Cultural concept presents the essential and integral element of linguistic consciousness widely investigated in Russian cultural linguistics. Culture concept is considered as a mental entity focused on overall study of language, culture and mind. Significance of language units that represent one or another cultural concept can be revealed by means of connotations that reflect evaluational world view of culturebearers (representatives of certain culture).In terms of various linguistic units so-called "core" (genuine part) of the culture concept transmits the peculiarities of mentality, national character and cultural values fixed in outworld of collective consciousness of peoplehood. Different culture concepts reveal the reality expressed in various symbols and signs determined in its absolute sense and enounced in language, art and culture. Therefore, through the prism of the comprehension of the essence of cultural concept, the correlation between language and culture becomes absolutely evident. In this regard it seems rational Jacques Lacans's utterance about the central role of the language in general in human's psychology: "I would say that this law of subjectivity which analysis especially highlights, its fundamental dependence on language is something which is so essential that it brings all the psychologies together" [1].
Intercultural communication, being some sort of synthesis among different forms of interaction between various culture-bearers, is deeply integrated in the notion of cultural concept. The notion of culture concept is closely connected with the language, tradition, history and cannot exist without being objectified by linguistic units. According W. von Humboldt, it is in society where the language obtains magnificent opportunities for its expanding and perfection. H.-J. Hadamer, presenting the language as the medium of hermeneutic experience, marked that it is inseparably associated with the tradition: "The essential relation between language and understanding is seen primarily in the fact that the essence of tradition is to exist in the medium of language, so that the preferred object of interpretation is a verbal one" [2].

Constant interaction and inter-influence of language, culture and its reflection in discourse that is always exposed in the notion of culture concept is also observed by M.Heidegger. It is being noted, in particular, that "The existential ontological foundation of language is discourse or talk. This phenomenon is one of which we have been making constant use already in our foregoing interpretation of stateof-mind, understanding, interpretation, and assertion... Discourse is existentially equiprimordial with state-of-mind and understanding" [3].

Therefore, becomes apparent the indispensability of the precise study of the culture concept issue.

\section{SURVEY OF CULTURE CONCEPT RESEARCH IN RUSSIA}

Culture concept, being the fundamental notion of the evaluational world view of certain peoplehood, is deeply investigated in Russian linguistics and philology. Evaluational world view, also called outworld view, is determined by linguistic units and formed by the entities of culture concepts that is specified according D. Likchachov, great Russian linguist, as sphere of concepts. Nation's culture wealth is measured by the richness of its sphere of concepts, considers D. Likchachov's [4].

Representing one of the key terms of cognitive linguistics, the notion of culture concept can be referred at the same time to philosophy, psychology, social stidies and 
ethnic studies. Interdisciplinary approach to the study of essence of the culture concept provides more opportunities for its precise analysis.

In modern Russian and world linguistics it is roughly distinguished four scientific trends that envisage culture concept as a mental formation in terms of language units. It is distinguished so-called psycholinguistic research school, ethnographical research school, so-called "linguo-cognitive" and cultural trends in the investigation of the cultural concept. In the context of psycholinguistics and metalinguistics, the culture concept issue was investigated mainly by S. Askoldov-Alekseev (proceeded by A. Zalevskaya); "linguo-cognitive" study of culture concepts is presented by scientific works of A. Wierzbicka, E. Kubryakova, E. Lassan, Z. Popova, I. Sternin; ethnographical study of the above mentioned unit was mainly conducted by N. Arutyunova. As for so-called cultural study of the concept in linguistics, outstanding Russian scientists, such as S. Vorkachev, V. Vorobiev, I. Zykova, V. Karasik, M. Kovshova, V. Maslova, G. Slyshkin, Y. Stepanov, O. Tchesnokova, V. Telia, V. Shaklein are distinguished. Scholary traditions are being developed in the major cities of Russia, such as Moscow, Saint-Petersburg, Krasnodar, Volgograd and former CIS countries. Despite the visual abundance of the scientific schools investigating culture concept, it seems evident that all the above mentioned trends are closely related to each other.

E. Vereshchagin and V. Kostomarov launched the investigation process of exploring the cultural concept from the linguoculturological point of view. Later it was proceeded by V. Vorobiev and V. Shaklein. V. Vorobiev, one of the founders of Russian school of cultural conceptology, highlights, that the major task of the cultural linguistics (linguoculturology) is to explore the evaluational world view and its diversities in national characters of different nations. It is emphasized that the immersion of words into culture reveals extralinguistic semantics that permits to understand cultural specifics in a more detailed way [5]. To make it clear, it is needed to precise that in Russian cognitive linguistics such terms as "cultural" and "linguocultural" are used as partial synonyms; the latter is often objectified by language units. The terms "linguoculturology" and "linguoculturological" stir up disputes and controversies and sometimes are considered as linguistic calque. However, both of them are widely used in scientific works. Equally it is often remarked that system of cognitive linguistic terms in Russian humanities is overwhelmed, that is notably mentioned by E. Lassan [6].

Herein we keep to the fundamental premises of the culture concept from the cognitive linguistics point of view and follow S. Vorkachev. Linguocultural conceptology presents one of the branches of Russian anthropological linguistics. Linguocultural concept, being the fundamental notion of anthropological linguistics, possesses, as it is mentioned by S. Vorkachev, "a set of differential features most important of which is the presence of various different components reflecting the interdisciplinary character of this discipline in its semantics" [7]. The scientist mentions the cross-disciplinary features that characterize the essence of cultural concept that permits to consider this cognitive unit as fundamental in depicting the interpretation of outworld, peculiarities of mentality and national character of people.

By reason of the presence of metaphoric and figurative integral part in the cultural concept as a cognitive unit, it is proper to say that the abovementioned unit possesses a great number of diversified attributes that enables to acknowledge the flexible character of the linguocultural conceptology as a science. Therefore, appears the capability of the cultural concept to reflect absolutely different culture-specific elements of the human being, including spiritual, social and material realias.

\section{CONCEPTS OF CULTURE INVESTIGATED IN RUSSIAN LINGUISTICS}

Culture concepts, acting as multidimensional mental complexes, reflect the ethnocultural heritage and diversities as well as the specifics of mentality and national character. They are objectified in various language units, such as phraseology (paroemias) and lexical units, being analyzed from different points of view and manifest varied phenomenon, items and subjects of human culture possessing great difference in its semantics. Culture concepts are capable to reflect the perception of so-called material, spiritual and social realias of human being, verbalize them and include notional (ideal), imaginative (descriptive, figurative, metaphorical) and axiological aspects. The latter often includes also the culture value aspect. The sensory image of the culture concept presents its essential part, thanks to which the semantics of the culture concept can be determined.

In Russian cognitive linguistics culture concepts are mainly studied via use of contrastive, comparative and linguoculturological methods. Be it noted that language units that verbalize different concepts of human culture are envisaged in comparison in various Indo-European languages, such as English, German, French, Spanish, Italian, Latin, Portuguese, Finnish, Swedish, Lithuanian, Lettish, etc.

Concerning spiritual culture concepts which analysis constitutes the major part of scientific works, following investigations are distinguished. Verbalization of culture concept "Sin" by E. Semuhina is presented in French and Russian evalutional world view. Regarding the definition of the notion "concept" it is highlighted notably the appurtenance of the latter to philosophy; their correlation is underlined, as follows: the concept is investigated as the notion of practical philosophy and presents, according the author, metalanguage of the culture [8].

Phraseological units such as paroemias (proverbs and sayings) nominating concept "Love" are being analyzed in comparison in Swedish, German, English and Russian languages by A. Aleshin. Paroemias verbalizing abovementioned concept of culture are classified into six thematic groups according their semantic criteria. It is proved that language universals that verbalize the notion of love in four investigated languages are based mainly on 
peoples' traditions, religion and folk literature [9]. For example, the author mentions that in German, Swedish and Russian languages the notion of love is being verbalized in similar way meaning that it is impossible to love someone by force that is clearly reflected in phraseology, for example: "Kärleken tål inget tvång" in Swedish, "Liebe duldet keinen Zwang", "Liebe läßt sich nicht erzwingen" in German, “Любовь не милостыня, её каждому не подашь" in Russian [10].

Culture concept "Happiness" as exemplified in Slavic languages is studied by T. Vladimirova. The author attempts to illustrate so-called "Russian language being" and peculiarities of its conceptualization by longuocognitive analysis of paroemias denoting cultural concept "Happiness". Analysis of above mentioned existential concept permitted to deduce that proverbs and sayings reflect axiological and semantic potential that has considerably increased from the period of Christianization of Russia [11]. It is highlighted the interdependence of philosophy, language and culture and noted that proverbs and sayings can be considered as one of the most reliable source that reveals the existential worldview of human being.

Among other concepts that verbalize spiritual and culture realias, it is curious to note research works conducted by O. Tchesnokova dedicated to the analysis of the Mexican evaluational world view, notably concerning the verbalization of the concept "Death". It is mentioned the possibility of the classification of phraseological units denoting abovementioned realia of the human being and highlights its role in the tradition and religion of the Mexicans. Language units that objectify concept "Farewell", another spiritual realia, are studied from the philosophical point of view by E. Lassan. It is noted that "the concept itself, in Foucault's terminology, may be assigned to the concepts of discontinuity, assuming thresholds, transformations - in one case this is the transformation of a personality" [12].

Among social concepts that nominate various culture realias, it is worth mentioning those that verbalize objects of gastronomic culture that are mainly studied in Mediterranean outworld. Language units that objectify basic alimentary products as bread(Spanish and Russian linguoculture), are investigated notably by V. Sinyachkin, S. Frolov; maize cob (Mexican culture) is studied mainly by O. Tchesnokova; wine as a cultural value and realia in French, Italian, Spanish, English and Russian linguocultural world is envisaged by P. Loginova, K. Romanova, K. Grinenko.

Regarding above mentioned concept, for instance, it was determined that phraseological units concerning cultural concept "Wine" in French, Italian, Spanish, English and Russian linguoculture, present a considerable source of information that forms the axiological world of abovementioned cultures. It is notably mentioned that "lexemes related to the concept of wine in French, Italian, Spanish, English and Russian languages represent profound linguistic material that is worth being analyzed within the framework of intercultural communication, linguistics and cultural studies" [13].
For example, proverbs and sayings denoting cultural concept "wine" allow to specify similar personality traits of French, Italians, Spanish and English that permit to determinate the coincidence of some fragments in axiological world view of the abovementioned cultures, like attitude to women, for instance (women are compared to good wine): "If the landlady is fair, the wine is fair" in English, "Bon vin et femmes jolies sont deux agréables poisons" in French, "Donne senza vedere e vino senza sentire non se ne prende" in Italian, "Vinos y amores, los viejos son los mejores" in Spanish [14].

Thus, linguistic units that verbalize various culture concepts, notably wine, reflect different peculiarities, specifics of mentality and national character of the nations that is curious to envisage in comparison. For instance, it is distinguished courtesy and hedonism of French and Italians; vigorous and passionate temper that is typical for Spanish; epicurism and self-indulgence that specify Italian mentality; subtle humor of the English.

Material concepts of culture are being also objectivated in language units that is demonstrated for instance, in the works of M. Briedis. So-called "Money relations" are illustrated in paroemias based on Russian, Latvian, Lithuanian, German and English language material. It is highlighted that "Money and people's attitude towards them, and the relationships between people about money play a big role in human life and, therefore, have a significant place in proverbs"[15]. For example, in many languages it is clearly revealed that if someone is poor, all friends will disappear: "Draugs ir tikai tad, kad ir, bet ka nav, ta I druga nav" in Lettish; "Wer kein Geld hat, der hat auch keinen Freund" in German; "Денег не стало - и друзей не бывало" in Russian [16]. Therefore, by the means of phraseological units nominating money as a universal form of communication between people, differences and similarities of the nations' mentalities are clearly revealed.

\section{CONCLUSION}

Cultural concept represents one of the basic units of Russian cognitive linguistics and considered as multidimensional mental and verbal formation. In modern Russian linguistics conventionally are distinguished several approaches to comprehension and study of the cultural concept on the base of the language material.

Language units (mainly phraseological) are capable to verbalize absolutely various culture concepts, including spiritual, material and social realias of the human being and lifestyle. The majority of them are being investigated and reviewed in European languages in comparison that permits to emphasize similarities and differences of nations' mentality. Semantic features of the language units that denote culture concepts allow to understand better specifics of culture that are often related to traditions and religion of the people. The results of research works dedicated to the culture concepts' analysis in Russian linguistics promote to decrease difficulties of interpretation as well as translation of the language units that can be caused by the differences in 
perception of the culture concepts in European cultures as well as the absence or presence of similar connotations.

\section{REFERENCES}

[1] J. Lacan. The Seminar of Jacques Lacan. Book VI. Desire and its Interpretation.1958-1959, p.9. Electronic Publication: Digital Object Identifiers

(DOIs):http://www.lacaninireland.com/web/translations/seminars/

[2] G.-J. Gadamer. Truth and Method.New- York: CONTINUUM, 2006, p.391.

[3] M. Heidegger. Being and Time. Oxford: Blackwell Publishers Ltd, 1962, p.203.

[4] D. Likchachov. Sphere of concepts of the Russian language/ D. Likchachov// "Russkayaslovesnost"magazine. Moscow, 1997, p 5.

[5] V. Vorobiev. Linguoculturology (theory and methods). Monograph. Moscow, RUDN publishing house, 1997, p.48.

[6] E. Lassan. Farewell - a sorrowful word (farewell - a genre, a concept, a speech act?)// Russian Journal of Linguistics, Vestnik RUDN. Number 3, 2015, p.10.

[7] S. Vorkachev. EX PLURIBUS UNUM: Linguocultural concept as an integral entity// Russian Journal of Linguistics, Vestnik RUDN. Volume 20, number 2, 2016, p.28.

[8] E. Semuhina. Verbalization of concept "Sin"in national outworld. Ph. D. thesis. Saratov, 2008, p.42.

[9] A. Aleshin. Paroemias nominating concept "Love"in Swedish, German, English and Russian languages (linguoculturological aspect)// Paramiology in discourse: General and applied problems of paramiology. Proverb in text and in discourse. Proverb and linguistic outworld.Moscow, LENLAND publishing house, 2015, p.189.

[10] A. Aleshin. Paroemias nominating concept "Love"in Swedish, German, English and Russian languages (linguoculturological aspect)//Paramiology in discourse: General and appliedproblems of paramiology. Proverb in text and in discourse.Proverb andlinguistic outworld.Moscow, LENLAND publishing house, 2015, pp.158-159.

[11] T. Vladimirova. Concept "Happiness" in Russian proverbial outworld// Paramiology in discourse: General and appliedproblems of paramiology. Proverb in text and in discourse. Proverb andlinguistic outworld.Moscow, LENLANDpublishing house, 2015, p.229.

[12] E. Lassan. Farewell - a sorrowful word (farewell - a genre, a concept, a speech act?)// Russian Journal of Linguistics, Vestnik RUDN. Number 3, 2015, p.7.

[13] P. Loginova. Perception of the cultural concept of wine in French, Italian, Spanish, English and Russian axiological world view based on contrastive analysis of paroemias. Thesis abstract.Moscow, 2017, p.23.

[14] P. Loginova. Perception of the cultural concept of wine in French, Italian, Spanish, English and Russian axiological world view based on contrastive analysis of paroemias. Ph. D. thesis. Moscow, 2017, p.314-315.

[15] Briedis M. Money Relations in the Provebs in the Light of Cultural Linguistics (on the Base of Russian, Latvian, Lithuanian, German and English). Zmogusiržodis 2013 III Lingvistika, p.17.

[16] Briedis M. Linguoculturological model of money relations represented in paroemias (based on the language units of Russian, Lettish, Lithuanian, German and English languages// Paramiology in discourse: General and applied problems of paramiology. Proverb in text and in discourse.Proverb and linguistic outworld. Moscow, LENLAND publishing house, 2015, p.203. 